\title{
Effect of Feeding and Starvation Intervals on the Performance and Productivity of the Silkworm Bombyx mori L.
}

\author{
Mona M. Mahmoud and Samia M. El-Hattab ${ }^{1}$
}

\begin{abstract}
Larvae of Bombyx mori L. were significantly affected by the number of daily meals offered to them. Larvae fed four or five times / day gave the highest records on the larval duration, weights of larvae, pupa, length and weight of female reproductive system. The lower weights were calculated from larvae fed by two meals / day. Insignificant differences were recorded on their pupal stage duration, length of female reproductive system, number of deposited eggs and hatchability. While, starvation gave a high significant effect on the decreased weights of larvae, pupa, silk gland, fresh cocoons and cocoon shell. Number of deposited eggs and hatchability didn't give any significant differences between number of meals offered to the tested larvae and starvation intervals.
\end{abstract}

\section{INTRODUCTION}

In several phytophagous insects, feeding behavior occurs regularly. It is well known that the fourth and fifth instars of silkworm Bombyx mori L. are the real feeding stage, where the larvae consume about $85.9 \%$ of the total consumed food.

The adequate quantity of offered mulberry leaves is important in silkworm rearing (Hosseini et al., 2005). Also, in another insects the level of feeding is a limiting factor, which affect the weights of larvae or the growth rate and fecundity of females (Hanna et al., 1977; Weaver and Pratt 1981 and Smith 1986).

In addition, starvation has a great unprofitable effect on the developing larvae of Philosamia ricini (Kapil, 1964).

Herein, the offered daily meals indicate more or less effectuality on the developmental fitness components of the Bombyx mori.

The present study was carried out to find out the suitable number of daily meals and determine the effect of starvation on the developmental parameters of silkworm.

\section{MATERIALS AND METHODS}

The newly hatched larvae from the Chinese hybrid 9F7X of the mulberry silkworm Bombyx mori L. were reared in the laboratory with standard rearing technique as discribed by (Krishnaswami, 1973) under hygrothermic conditions of $26 \pm 1.5^{\circ} \mathrm{c}$ and $80 \pm 5 \%$.
The larvae were reared in one group up to $4^{\text {th }}$ ecdysis. All of the moulted larvae at the same day were divided into two groups in separate trays.

The $1^{\text {st }}$ group was divided to four treatments of feeding regimes including meals at two, three four and five times / day on fresh picked mulberry leaves.

The $2^{\text {nd }}$ group was divided to another four treatments of starvation regimes; whereas the larvae were fed and starved day after day at the same adopted feeding times in the $1^{\text {st }}$ group.

Each treatment was replicated three times with 50 larvae / each. The developmental durations of larval and pupal stages were recorded. Fresh weights of $5^{\text {th }}$ instar larva, fresh cocoons, pupae and cocoon shells were measured.

Also, the number of deposited eggs/female moth was counted and recorded. Prior to spinning cocoons, five samples of mature larvae from each treatment were dissected, the silk glands were drawn and the length and weight of each was measured.

Also, samples of the newly emerged female moths were dissected in Ringer solution; the reproductive system of each female was removed, the length and weight of each reproductive system was measured.

Hatchability was estimated according to the following formula of Lea (1996):

Hatchability $\%=\mathrm{H} / \mathrm{F} \times 100$

Where, $\mathrm{H}=$ Number of hatched larvae.

$$
\mathrm{F}=\text { Number of deposited eggs. }
$$

Results were expressed as mean values plus or minus the standard deviation. All tested criteria of the subject insect were statistically analyzed and compared using " $F$ " test, " $t$ " test and least significant difference (L.S.D.) at 5\% probability level, (Senedecor, 1956).

\section{RESULTS AND DISCUSSION}

1- Effect of number of offered daily meals on the fitness components of the silkworm Bombyx mori $\mathrm{L}$.

The demonstrated results in Table 1, show that the prolonged period of larval and pupal duration were mainly detected for those larvae fed by two daily meals

\footnotetext{
${ }^{1}$ Sericulture Dept., Plant Protection Res. Institute ARC,

Alex., Egypt.

Received November 1, 2012, Accepted December 13, 2012.
} 
(12 and 16 days), respectively; the shortest larval duration of 10 days was obtained for those fed by four and five daily meals.

It is also noticed that the highest value of larval and pupal weight (2.817 and $1.08 \mathrm{gm}$.) in respect, had been attained in case of offering five daily meals. Larvae fed on 2 meals / day comprised the lightest weight for larva and pupa (2.534 and $0.861 \mathrm{gm}$.) respectively.

Generally, the offered daily meals have a positive effect on the developmental fitness components of the silkworm Bombyx mori L.

A significant difference between the averages of measured length and weight of larval silk glands was obtained. Larvae fed by five meals / day gave the tallest length and heaviest weight of silk gland $(26 \mathrm{~cm}$ and 0,734 g.), respectively. While larvae fed by two meals / day only gave the shortest and lightest measures $(21 \mathrm{~cm}$ and $0.633 \mathrm{~g}$.), in respect.

Salem (1974) determined the increase in the weight of Philosamia ricini silk gland when the number of daily meals increased. A Same trend of results was reported by Ceausescu et al. (1977) and El-Sayed (1989).
The obtained results in Table 1, also show the detected highly significant differences between the calculated average weights of fresh cocoon and cocoon shell due to the varied numbers of offered daily meals. The same trend of results was stated by He et al., (1987) who reported that larvae of silkworm Bombyx mori fed 2 or 3 times daily had lower cocoon weights and cocoon layers compared with those fed 4 times daily. Mahmoud and Yehia (2008) found that larvae of silkworm Bombyx mori $\mathrm{L}$. fed three or four times a day on mulberry leaves gave the heaviest weights of mature larvae, silk glands, pupae, fresh cocoon and egg production.

2- Effect of the number of offered daily meals on the reproductivity of the silkworm Bombyx mori $\mathrm{L}$.

The illustrated results in Table 2, elucidate that the number of deposited eggs / female and weight of female reproductive system (R.S.) were insignificantly differed in all of the performed treatments, while the calculated averages length of female (R.S.) were quietly significantly differed depending on the number of introduced daily meals. Whereas, the larvae fed by five meals / day gave the tallest (R.S.) length $(13.06 \mathrm{~cm})$.

Table 1. Effect of the number of offered daily meals on the fitness components of the silkworm Bombyx mori L.

\begin{tabular}{|c|c|c|c|c|c|c|c|c|}
\hline $\begin{array}{l}\text { No. of } \\
\text { Daily meals }\end{array}$ & $\begin{array}{c}\text { Larval } \\
\text { duration } \\
\text { (days) }\end{array}$ & $\begin{array}{c}\text { Wt. of larva } \\
\text { (g.) } \\
\text { A }\end{array}$ & $\begin{array}{c}\text { Pupal } \\
\text { duration } \\
\text { (days) }\end{array}$ & $\begin{array}{l}\text { Wt. of pupa } \\
\text { (g.) } \\
\text { B }\end{array}$ & $\begin{array}{l}\text { Length of } \\
\text { silk gland } \\
(\mathrm{cm}) \\
\text { C }\end{array}$ & $\begin{array}{l}\text { Wt. of fresh } \\
\text { silk gland (g.) } \\
\text { C }\end{array}$ & $\begin{array}{l}\text { Single fresh } \\
\text { cocoon wt. } \\
\text { (g.) } \\
\text { B }\end{array}$ & $\begin{array}{l}\text { Cocoon } \\
\text { shell wt. (g) } \\
\quad \text { B }\end{array}$ \\
\hline $2 \mathrm{M}$ & 12 & $\begin{array}{l}2.534 \quad c \\
\pm 0.1592\end{array}$ & 16 & $\begin{array}{l}0.861 \mathrm{~d} \\
\pm 0.1381\end{array}$ & $\begin{array}{l}21 \mathrm{~b} \\
\pm 1\end{array}$ & $\begin{array}{l}0.633 \quad c \\
\pm 0.0722\end{array}$ & $\begin{array}{l}1.072 \mathrm{~d} \\
\pm 0.1497\end{array}$ & $\begin{array}{l}0.21 \quad \mathrm{~d} \\
\pm 0.0211\end{array}$ \\
\hline $3 \mathrm{M}$ & 11 & $\begin{array}{l}2.683 \quad b \\
\pm 0.1319\end{array}$ & 15 & $\begin{array}{l}0.979 \quad \mathrm{c} \\
\pm 0.1093\end{array}$ & $\begin{array}{l}21.2 \quad b \\
\pm 0.8366\end{array}$ & $\begin{array}{l}0.667 \quad b \\
\pm 0.0562\end{array}$ & $\begin{array}{l}1.209 \quad \mathrm{c} \\
\pm 0.1098\end{array}$ & $\begin{array}{l}0.23 \quad c \\
\pm 0.0134\end{array}$ \\
\hline $4 \mathrm{M}$ & 10 & $\begin{array}{l}2.683 \quad b \\
\pm 0.1303\end{array}$ & 15 & $\begin{array}{l}1.057 \quad \mathrm{~b} \\
\pm 0.0752\end{array}$ & $\begin{array}{l}23.4 \quad \mathrm{ab} \\
\pm 2.6076\end{array}$ & $\begin{array}{l}0.733 \quad \mathrm{a} \\
\pm 0.0206\end{array}$ & $\begin{array}{c}1.299 \mathrm{~b} \\
\pm 0.091\end{array}$ & $\begin{array}{l}0.241 \quad b \\
\pm 0.2419\end{array}$ \\
\hline $5 \mathrm{M}$ & 10 & $\begin{array}{l}2.817 \quad \text { a } \\
\pm 0.1012\end{array}$ & 15 & $\begin{array}{l}1.08 \quad \mathrm{a} \\
\pm 0.0694\end{array}$ & $\begin{array}{c}26 \text { a } \\
\pm 1\end{array}$ & $\begin{array}{l}0.734 \quad \mathrm{a} \\
\pm 0.0218\end{array}$ & $\begin{array}{l}1.323 \quad \mathrm{a} \\
\pm 0.066\end{array}$ & $\begin{array}{l}0.243 \text { a } \\
\pm 0.0204\end{array}$ \\
\hline
\end{tabular}

Each value represents the mean \pm S.D. of $A=15, B=10$ and $C=5$ replicates.

*Means followed by same letter(s) are not significantly different.

Table 2. Effect of the number of offered daily meals on the reproductivity of the silkworm Bombyx mori L.

\begin{tabular}{|c|c|c|c|c|}
\hline $\begin{array}{l}\text { Characters } \\
\text { No. of } \\
\text { Daily meals }\end{array}$ & No. of dep.eggs/female & Length of (R.S.)Cm & Wt. of R.S.(g.) & Hatchability \% \\
\hline $2 \mathrm{M}$ & $\begin{array}{l}458.8 \\
\pm 66.126 \\
\end{array}$ & $\begin{array}{l}10.04 \mathrm{~d} \\
\pm 0.364\end{array}$ & $\begin{array}{l}0.455 \\
\pm 0.014\end{array}$ & $\begin{array}{l}89.633 b \\
\pm 2.276\end{array}$ \\
\hline $3 \mathrm{M}$ & $\begin{array}{l}469.2 \\
\pm 41.433\end{array}$ & $\begin{array}{l}10.72 c \\
\pm 0.216\end{array}$ & $\begin{array}{l}0.493 \\
\pm 0.043\end{array}$ & $\begin{array}{l}90.125 \text { ab } \\
\pm 2.665\end{array}$ \\
\hline $4 \mathrm{M}$ & $\begin{array}{l}495.6 \\
\pm 21.349\end{array}$ & $\begin{array}{ll}11.62 & b \\
\pm 0.46 & \end{array}$ & $\begin{array}{l}0.501 \\
\pm 0.053\end{array}$ & $\begin{array}{l}93.212 \mathrm{ab} \\
\pm 1.504\end{array}$ \\
\hline $5 \mathrm{M}$ & $\begin{array}{l}530.2 \\
\pm 44.84\end{array}$ & $\begin{array}{l}13.06 \quad a \\
\pm 0.403\end{array}$ & $\begin{array}{l}0.518 \\
\pm 0.038\end{array}$ & $\begin{array}{l}95.646 \quad \mathrm{a} \\
\pm 1.76\end{array}$ \\
\hline
\end{tabular}

Each value represents the mean \pm S.D. of 5 replicates.

*Means followed by same letter(s) are not significantly different. 
These results are in accordance with Baud (1955) and Johanson (1966) who found that diet is an important factor for female moth production. Also, El-Sayed (1989) recorded insignificant differences between the numbers of deposited eggs / female when different meals were offered to the eri - silkworm Philosamia ricini.

Concerning the percentage of hatched eggs, it is noticed that the estimated percent values of hatchability were merely the same except in larvae fed by two meals / day which gave the lowest value of $89.633 \%$.

The obtained results are supported by these obtained by Salem (1974) who determined the fertility and fecundity of Philosamia ricini moths distinctly depend on the derived food reserves from larvae. Besides to, ElSayed (1989) also found insignificant differences between the deduced (\%) values of hatched eggs in all initiated treatments on the eri - silkworm.

3- Effect of feeding and starvation sequency on the fitness components of the silkworm Bombyx mori L.

In this trial the fifth instar larvae were fed on two, three, four and five daily meals, and then followed by starvation period along twenty four hrs. until the end of larval develpoment. The measured developmental characteristics were compared with those obtained for control larvae, which were fed on the corresponding number of daily meals without starvation.

The included results in Table 3, show that the larval duration and larval weight were significantly affected by the starvation of the tested larvae. Opposite results were recorded for the pupal duration which was not affected by the offered daily meals sequenced by starvation intervals. The measured weights of derived pupae were highly significantly affected. This significance was also recorded in all treatments for the weight of fresh silk gland, cocoon weight and cocoon shell weight. While, the silk gland length was significantly decreased in all offered daily meals and consequent starvation, except the case of four daily meals no significant difference was recorded.

These results are similar to those reported by Srivastava and Nath (1982); Srivastava et al. (1984) and El-Sayed (1989) who studied the effect of starvation on the weight of cocoon of eri - silkworm Philosamia ricini. They found a decrease in the cocoon shell weight due to deprivation during feeding period. In addition, Morita and Tojo (1985) found that larval starvation affected the pupal weights of the common cutworm Spodoptera litura.

\section{4- Effect of feeding and starvation sequence on the reproductivity of the silkworm Bombyx mori $\mathrm{L}$.}

The presented results in Table 4, elucidate insignificant differences among the calculated mean numbers of deposited eggs and hatchability, the only exception occurred when the larvae were fed twice a day, then followed by a starvation period which gave significant decrease than the control. Moreover, significant difference was obtained in all treatments concerning the length and weight of reproductive system.

Table 3. Effect of starvation sequency on the fitness components of the silkworm Bombyx mori $\mathrm{L}$.

\begin{tabular}{|c|c|c|c|c|c|c|c|c|}
\hline $\begin{array}{l}\text { no. of meals \& starvation } \\
\text { characters }\end{array}$ & $2 M$ & $\mathbf{S}^{*}$ & 3M & $\mathbf{S}$ & $4 M$ & $\mathbf{S}$ & $5 \mathbf{M}$ & $\mathbf{S}$ \\
\hline Larval duration (day) & 12 & 14 & 11 & 14 & 10 & 13 & 10 & 12 \\
\hline \multirow[t]{2}{*}{ Wt.of larva (gm) } & 2.534 & 1.543 & 2.683 & 2.049 & 2.683 & 2.448 & 2.817 & 2.472 \\
\hline & \multicolumn{2}{|c|}{ t.val. $18.865^{* *}$} & \multicolumn{2}{|c|}{ t.val. $12.863^{* *}$} & \multicolumn{2}{|c|}{ t.val. $4.299 * *$} & \multicolumn{2}{|c|}{ t.val. $8.302 * *$} \\
\hline Pupal duration (days) & 16 & 16 & 15 & 15 & 15 & 15 & 15 & 15 \\
\hline \multirow[t]{2}{*}{ Wt. of pupa (gm) } & 0.861 & 0.699 & 0.979 & 0.815 & 1.057 & 0.842 & 1.08 & 0.897 \\
\hline & \multicolumn{2}{|c|}{ t.val. $3.336^{* *}$} & \multicolumn{2}{|c|}{ t.val. $3.408 * *$} & \multicolumn{2}{|c|}{ t.val. $4.328 * *$} & \multicolumn{2}{|c|}{ t.val. 5.244** } \\
\hline \multirow[t]{2}{*}{ Length of silk gland $(\mathrm{cm})$} & 21 & 14.8 & 21.2 & 17.8 & 23.4 & 21 & 26 & 21.8 \\
\hline & \multicolumn{2}{|c|}{ t.val. $10.632 *$} & \multicolumn{2}{|c|}{ t.val. $6.425^{*}$} & \multicolumn{2}{|c|}{ t.val. $1.862 \mathrm{~N} . \mathrm{S}$. } & \multicolumn{2}{|c|}{ t.val. $5.715^{*}$} \\
\hline \multirow{2}{*}{ Wt. of fresh silk gland (gm) } & 0.633 & 0.271 & 0.667 & 0.387 & 0.733 & 0.478 & 0.734 & 0.467 \\
\hline & \multicolumn{2}{|c|}{ t.val. $11.051 * *$} & \multicolumn{2}{|c|}{ t.val. $7.04 * *$} & \multicolumn{2}{|c|}{ t.val. $12.365^{* *}$} & \multicolumn{2}{|c|}{ t.val. $11.384 * *$} \\
\hline \multirow[t]{2}{*}{ Single fresh cocoon wt. (gm) } & 1.072 & 0.869 & 1.209 & 0.995 & 1.299 & 1.023 & 1.323 & 1.109 \\
\hline & \multicolumn{2}{|c|}{ t.val. $3.83 * *$} & \multicolumn{2}{|c|}{ t.val. $4.222 * *$} & \multicolumn{2}{|c|}{ t.val. $5.522 * *$} & \multicolumn{2}{|c|}{ t.val. $6.232 * *$} \\
\hline \multirow[t]{2}{*}{ Cocoon shell wt. (gm) } & 0.21 & 0.169 & 0.23 & 0.179 & 0.241 & 0.18 & 0.243 & 0.211 \\
\hline & \multicolumn{2}{|c|}{ t.val. $4.648^{* *}$} & \multicolumn{2}{|c|}{ t.val. $6.45^{* *}$} & \multicolumn{2}{|c|}{ t.val. $6.255^{* *}$} & \multicolumn{2}{|c|}{ t.val. $3.971^{* *}$} \\
\hline est & $=$ highly & nnificant & & ficant & N.S. $=$ & signific & & \\
\hline
\end{tabular}


Table 4. Effect of feeding and starvation sequency on the reproductivity of the silkworm Bombyx mori L.

\begin{tabular}{|c|c|c|c|c|c|c|c|c|}
\hline $\begin{array}{l}\text { No. of meals \& } \\
\text { starvation } \\
\text { characters }\end{array}$ & $2 \mathrm{M}$ & $S^{*}$ & $3 \mathbf{M}$ & $\mathbf{S}$ & $4 M$ & $\mathbf{S}$ & $5 \mathbf{M}$ & $\mathbf{S}$ \\
\hline $\begin{array}{l}\text { No. of dep. } \\
\text { eggs/female }\end{array}$ & $\begin{array}{r}458.8 \\
\text { t.val }\end{array}$ & $\begin{array}{l}341.5 \\
31 * *\end{array}$ & $\begin{array}{r}469.2 \\
\text { t.val. }\end{array}$ & $\begin{array}{l}434 \\
\text { N.S. }\end{array}$ & $\begin{array}{r}495.6 \\
\text { t.val }\end{array}$ & $\begin{array}{l}474.8 \\
4 \text { N.S. }\end{array}$ & $\begin{array}{r}530.2 \\
\text { t.val }\end{array}$ & $\begin{array}{l}476.6 \\
\text { N.S. }\end{array}$ \\
\hline $\begin{array}{c}\text { Length of } \\
\text { (R.S.) } \\
\text { cm /female }\end{array}$ & \multicolumn{2}{|c|}{ t.val. $3.373^{* *}$} & \multicolumn{2}{|c|}{ t.val. $11.115^{* *}$} & \multicolumn{2}{|c|}{ t.val. $6.215^{* *}$} & \multicolumn{2}{|c|}{ t.val. $10.053^{* *}$} \\
\hline $\begin{array}{c}\text { Wt. of } \\
\text { (R.S.)Gm }\end{array}$ & \multicolumn{2}{|c|}{ t.val. $5.457 * *$} & $\begin{array}{r}0.493 \\
\text { t.va }\end{array}$ & $\begin{array}{l}0.421 \\
62 *\end{array}$ & $\begin{array}{r}0.501 \\
\text { t.v }\end{array}$ & $\begin{array}{l}0.434 \\
389^{*}\end{array}$ & $\begin{array}{r}0.518 \\
\text { t.va }\end{array}$ & $\begin{array}{l}0.44 \\
2 * *\end{array}$ \\
\hline $\begin{array}{c}\text { Hatchability } \\
\%\end{array}$ & $\begin{array}{r}85.44 \\
\text { t.val }\end{array}$ & $\begin{array}{l}83.908 \\
38^{*} \\
\end{array}$ & \multicolumn{2}{|c|}{ t.val. $2.184 \mathrm{~N} . \mathrm{S}$. } & $\begin{array}{r}93.26 \\
\text { t.val } \\
\end{array}$ & $\begin{array}{l}91.945 \\
3 \text { N.S. } \\
\end{array}$ & t.val. 0.976N.S. & $\begin{array}{l}94.27 \\
\text { N.S. } \\
\end{array}$ \\
\hline
\end{tabular}

T. val. $=$ deduced of $\mathrm{t}$ test $\quad * *=$ highly significant

$\mathrm{S}^{*}=$ starved larvae day after day.

These results are in accordance with those obtained by El-Sayed (1989) who recorded that the hatchability were statistically insignificant in all conducted treatments of larval starvation throughout the rearing period of the Eri - silkworm Philosamia ricini Boisd.

\section{REFERENCES}

Baud, L. (1955). The influence of quantitative under feeding during the last intermoult of $B$. mori L. on its final development and on the next generation. Rev. Ver. Soie, 7: $73-157$.

Ceausescu, S.; A. Mihaescu; V. Horeanga and M. Radulescu (1977). The determination of the amino acids in the food and silk of Philosamia ricini (Lepidoptera, Saturnidae). An. Univ. Bucur Biol. 26 (0): 107 - 110.

El-Sayed, Nagda A. A. (1989). Factors affecting the activity of corpora allata and their hormonal involvement in certain metabolic processes during metamorphosis of the castor and cotton leaf worm. Ph. D. Thesis Fac. of Agric. Helwan Univ., Egypt.

Hanna, H. M.; N. E. F. Hamad and S. G. Azab (1977). Effect of photoperiod on the biology of the lesser cotton leaf worm, Spodoptera exigua (HB). Bull. Soc. Ent. Egypt, 61: 215-224.

He, Gi; W. Pz and Y. G Huang. (1987). Economic efficiency of scarce rearing of Bombyx mori. Gunagdong Agric. Sci., $3: 23-25$.

Hosseini, M. S. H., K. Etebari, S. Z. Mirhosseini and L. Matindoost (2005). Bio - Economic study on feeding frequency of silkworm (Bombyx mori L.). XXth Congress of the International Sericultural commission.

Johanson, A. S. (1966). Feeding and nutrition in reproductive processes in insects. Symp. R. Ent. Soc. Lond., 2: 43 - 55.

Kapil, R. M. (1964). Quantitative feedings of larvae of Philosamia ricini Boisd. J. Entomo., 25: 233 - 241.

Krishnaswami, S. (1973). Improved methods of rearing young (Chawki) silkworms. Central silk Board, Bangalore India, pp.24.

Lea, H. Z. (1996). Basic principles and practical techniques of silkworm breeding. Department of biology, Kangwon National University, Chun Chon, Korea.

Mahmoud, Mona M. and Wagiha H. Yehia (2008). Effect of shoot feeding method on the performance and productivity of silkworm Bombyx mori L. J. Agric. Res., 86(2): $839-$ 845.

Morita, M. and S. Tojo (1985). Relationship between starvation and supernumerary ecdysis and recognition of the penultimate Larval instar in the common cutworm, $S$. litura J. Insect Physiol., 31(4): 307 - 313.

Salem, M. S. (1974). Feeding of silkworm, Philosamia ricini Boisd., with consideration to silk productivity. Ph. D. thesis Fac. Agric. Cairo Univ.

Smith, A. H. (1986). Fecundity and survival of the common armyworm, Mythimna caneita. effects of temperature and larval nutrition. Entomol. Exp. Appl., 42: 31 - 37.

Snedecor, G. W. (1956). Statistical methods. $5^{\text {th }}$ ed., lowa State University Press, lowa, pp. 534.

Srivastave, U. S. and N. Nath (1982). Heamolymph free amino acids in the two sexes of the adult $P h$. ricini Hutt (Lepidoptera : Saturniidae). National Academy of Science letters, India, 5 (3): $107-110$.

Srivastave, U. S.; S. D. Misra and F. S. poonia (1984). Effect of food deprivation on larval duration, cocoon shell weight and fecundity of Eri - silkworm Philosamia ricini Indian J. Seric, 21 - 22 (0): 11 - 15.

Weaver, R. J. and G. E. Pratt (1981). Effects of starvation and feeding upon corpus allatum activity and oocyte growth in adult female Periplaneta americana. J. Insect Physoil.; 27 : $75-83$ 


\section{الملخص العربي}

\section{تأثير التغذية والتجويع على آداء وإنتاجية دودة الحرير التوتية}

منى ماهر محمود، سامية تحمَّة الحطاب

أجريت هذه التجربة لدراسة تاثير عدد مرات التغذية يوميا على لمأم يتأثر طول فترة العمر العذرى، كذلك عدد البيض الموضوع

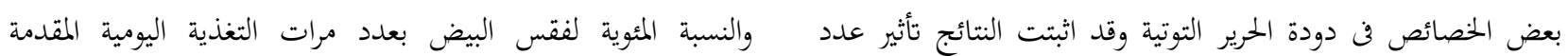

مرات التغذية اليومية بمعنوية كبيرة على كل من طول العمر اليرقى، وزن لليرقات.

ومن ناحية أخرى أثرت فترة تجويع اليرقات على مدى 24 ساعة

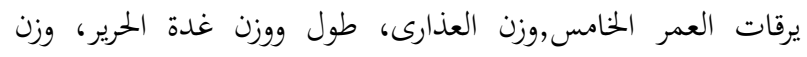

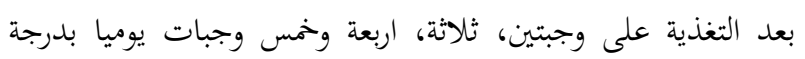

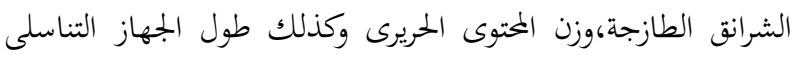

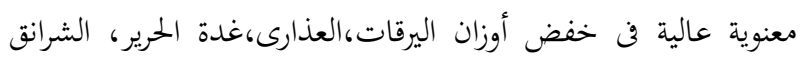

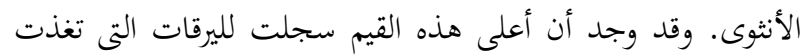

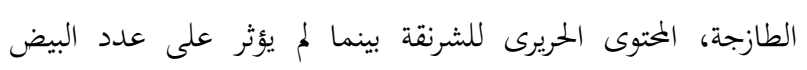

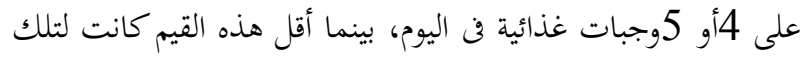
الموضوع ونسبة الفقس. اليرقات المرباة على وجبتين فن اليوم. 